\title{
AKTIVITAS ANTIJAMUR EKSTRAK ETANOL BUNGA KETEPENG CINA (Senna alata l) TERHADAP JAMUR Candida albicans
}

Adi Saputra' ${ }^{1}$, Tafdhila², Mayaranti Wilsya ${ }^{3}$

1,2, Program Studi D3 Keperawatan, Siti Khadijah, Palembang

3 Program Studi S-1 Farmasi, Siti Khadijah, Palembang adiebiomedik79@gmail.com

\begin{abstract}
ABSTRAK
Latar Belakang: Kulit merupakan organ terbesar dalam tubuh, luasnya sekitar $2 \mathrm{~m}^{2}$.Kulit merupakan bagian terluar dari tubuh manusia yang lentur dan lembut. Kulit merupakan benteng pertahanan pertama dari berbagai ancaman yang datang dari luar, seperti kuman, virus, jamur dan bakteri. Candida albicans merupakan jamur opportunistic penyebab infeksi pada kulit dan membran mukosa di dalam mulut yang dapat menyerang anak-anak maupun orang dewasa. Salah satu tanaman yang memiliki khasiat sebagai anti jamur adalah bunga ketepeng cina (Senna alata L.). Ketepeng Cina (Senna alata $L$ ) adalah salah satu tanaman tradisional yang dapat dimanfaatkan sebagai obat. Tujuan : penelitian ini bertujuan untuk mengetahui aktivitas antijamur ekstrak etanol bunga ketepeng cina (Senna alata L) terhadap jamur Candida albicans. Metode: penelitian ini adalah penelitian eksperimental, menggunakan ekstrak bunga ketepeng cina (Senna alata L.) menggunakan cara difusi untuk menguji aktivitas terhadap jamur Candida albicans. metode pengujian dilakukan Ekstraksi, Uji Skrining Fitokimia, Uji Aktivitas Antijamur. Hasil : hasil pengujian aktivitas antijamur menunjukkan bahwa ekstrak etanol bunga ketepeng cina (Senna alata L) mampu menghambat pertumbuhan jamur Candida albicans pada konsentrasi $40 \%$ sudah terlihat zona hambat dengan diameter rata-rata 7,1 mm. Simpulan : Bunga ketepeng Cina memberikan Efek terhadap anti jamur kandida albica.
\end{abstract}

Kata kunci : Bunga ketepeng cina, Aktifitas Antijamur, Candida albicans

\begin{abstract}
Background: Skin is the largest organ in the body, with an area of about $2 \mathrm{~m} 2$. Skin is the outermost part of the human body, which is flexible and soft. The skin is the first line of defense against various external threats, such as germs, viruses, fungi and bacteria. Candida albicans is an opportunistic fungus that causes infections of the skin and mucous membranes in the mouth that can attack both children and adults. One of the plants that have anti-fungal properties is the Chinese ketepeng flower (Senna alata L.). Ketepeng Cina (Senna Alata L) is one of the traditional plants that can be used as medicine. Aim: This study aimed to determine the antifungal activity of the ethanol extract of the Chinese ketepeng flower (Senna Alata L) against the fungus Candida albicans. Methods: This study was an experimental study, using an extract of the Chinese ketepeng flower (Senna alata L.) using a diffusion method to test its activity against the fungus Candida albicans. the test method is Extraction, Phytochemical Screening Test, Antifungal Activity Test. Results: the antifungal activity test results showed that the ethanolic extract of the Chinese ketepeng flower (Senna alata L) was able to inhibit the growth of the fungus Candida albicans at a concentration of $40 \%$. The inhibition zone had an average diameter of $7.1 \mathrm{~mm}$. Conclusion: Chinese ketepeng flower has an effect on the antifungal Candida albica.
\end{abstract}

Keywords: Ketepeng Cina Flower, Antifungal Activity, Candida Albicans 


\section{PENDAHULUAN}

Kulit merupakan organ terbesar dalam tubuh, luasnya sekitar $2 \mathrm{~m} 2$.Kulit merupakan bagian terluar dari tubuh manusia yang lentur dan lembut. Kulit ini penting dan merupakan permukaan luar organisme untuk membatasi lingkungan dalam tubuh dengan lingkungan luar. Kulit merupakan benteng pertahanan pertama dari berbagai ancaman yang datang dari luar, seperti kuman, virus, jamur dan bakteri. Kulit adalah lapisan-lapisan jaringan yang terdapat di seluruh bagian permukaan tubuh. Pada permukaan kulit terdapat kelenjar keringat dan kulit merupakan salah satu alat indera yaitu indera peraba karena di seluruh permukaan kulit terdapat saraf peraba (Juli Angriyasa, 2018).

Beberapa jenis jamur dapat terjangkit oleh kulit manusia. Ada sebagian jamur dapat menyerang jaringan yang terdapat kandungan zat tanduk misalnya kulit, kuku dan rambut. Namun ada juga infeksi jamur yang sering disebut dengan panu, pada umumnya kulit yang berlembab mudah terserang jamur. Area kulit yang sering terjangkiti jamur adalah area lipatanlipatan tubuh yang mudah lembab, orang gemuk, lipatan-lipatan perut atau payudara. Berikut beberapa faktor seseorang rentan terinfeki jamur adalah kulit lembab, daya tahan tubuh turun, konsumsi obat tertentu, diabetes mellitus atau kencing manis berlebihan tidak terkontrol dan lain (dr. Regina,2019).

Kasus penyakit kulit akibat kerja diseluruh dunia sekitar $40 \%$ dan $80 \%$ $90 \%$ diantaranya adalah dermatitis kontak iritan dan dermatitis kontak alergi (Setyaningrum \& Kemila, 2018). Penyakit kulit akibat kerja dan berdampak serius serta meningkatkan biaya kesehatan dan menurunkan kualitas hidup (Setyaningrum \& Kemila, 2018).

Di Indonesia, prevalensi Dermatits mengalami peningkatan setiap tahunnya. Penelitian oleh Soegiarto, tahun 2019, melaporkan bahwa morbiditas penyakit alergi pada anak sekolah di kota metropolitan di Indonesia memiliki pola yang sama dengan negara berkembang lainnya. Penelitian melibatkan 499 anak dan remaja dari sekolah dan universitas di 5 kota. Dilaporkan 278 subjek setidaknya memiliki satu manifestasi penyakit alergi, dimana kasus DA sebesar 1,8\%. Urtikariadan Rhinitisalergi merupakan penyakit atopik yang paling sering muncul, dengan riwayat keluarga atopik positif sebesar $60,79 \%$.

Menurut data rekam medik di RSUD Dr. H. Abdul Moeloek Bandar Lampung tahun 2017 sampai 2019 , terdapat 420 penderita dermatitis seboroik. Menurut data rekam medik di RSUD Dr. H. Abdul Moelek Bandar Lampung tahun 2018 total pasien dermatitis seboroik mencapai 106 orang dengan rata-rata 8 pasien setiap bulannya, sedangkan pada tahun 2019 jumlah seluruh pasien dermatitis seboroik mencapai 83 orang dengan rata-rata 7 pasien setiap bulannya. Salah satu jamur yang menyebabkan infeksi kulit adalah Candida albicans. Candida albicans merupakan jamur opportunistic penyebab infeksi pada kulit dan membran mukosa di dalam mulut yang dapat menyerang anakanak maupun orang dewasa (Rindi Astari, 2020).

Candida normal berada di kulit, membran mukosa, dan gastrointestinal (Irianto, 2013. Candida memiliki lebih dari 150 spesies dan terdapat 17 spesies yang dapat menginfeksi manusia. Infeksi Candida superfisial maupun sistemik yang terjadi pada manusia terutama disebabkan oleh Candida albicans yaitu sekitar 70-80\%, dan diikuti oleh Candida tropicalis sekitar 30-40\% (Maimunah, 2018).

Kandidiasis merupakan infeksi akibat jamur yang memiliki insiden tertinggi dibandingkan dengan jamur-jamur lainnya. Infeksi Candida sp meningkat dalam kurun waktu 20-25 tahun terakhir (Nelwan, 2014).

Perawatan kandidiasis dapat dilakukan dengan berbagai macam obat 
antijamur, baik secara kimia maupun tradisional. Seiring dengan berkembangnya ilmu pengetahuan dan teknologi, pemakaian dan penyalahgunaan obat tradisional mengalami kemajuan yang sangat pesat (Rohma, 2020). Sekitar 65$80 \%$ populasi dunia bergantung pada obat tradisional untuk memenuhi kebutuhan kesehatan primernya. Faktor keamanan dan pertimbangan harga menjadi nilai jual peningkatan penggunaan Obat tradisional (Siregar \& Suhendry, 2013).

Berbagai negara termasuk Indonesia telah bertahun - tahun menggunakan tanaman sebagai obat tradisional untuk mengatasi berbagai macam penyakit termasuk infeksi jamur Salah satu tanaman yang memiliki khasiat sebagai anti jamur adalah bunga ketepeng cina (Cassia alata L.). Ketepeng Cina (Cassia alata L.) merupakan tanaman yang cukup terkenal di masyarakat.

Menurut penelitian Chatterjee, (2013), daun Ketepeng Cina (Cassia alata L.) memiliki aktivitas antioksidan penarikan DPPH yang tinggi (IC50=54 \pm 2.20 ). Hal tersebut dikarenakan gelinggang mengandung senyawa flavonoid yangpada tanaman senyawa ini berfungsi sebagai pemberi efek antioksidan. Selain sebagai antioksidan, senyawa flavonoid pada tanaman juga berfungsi sebagai anti inflamasi, antialergi, antimikroba, serta antijamur untuk beberapa golongan.

Berdasarkan data empiris tumbuhan ini ternyata mempunyai banyak khasiatnya di samping untuk pengobatan penyakit akibat infeksi jamur. Dari beberapa hasil penelitian terdahulu telah terbukti bahwa ekstrak daun ketepeng cina berpengaruh terhadap pertumbuhan jamur, juga mempengaruhi perkembangan cacing perut, dapat mengatasi sembelit dan masih banyak lagi prospek farmatik lainnya.

Hal itu disebabkan oleh adanya kandungan zat antimicrobial yang bersifat fungistatik di dalamnya, sehingga dapat menghambat proses pemanjangan hifa (misellium) jamur dan akhirnya perkembangan jamur pun menjadi terhambat. Daun ketepeng cina dimanfaatkan orang zaman dahulu untuk mengobati berbagai macam penyakit 3 kulit seperti panu, kudis dan kurap. Pemilihan jamur Candida albicans dikarenakan jamur ini dapat menyerang organ ditubuh seperti kulit yang dimana merupakan infeksi yang sering terjadi dikalangan masyarakat.

Berdasarkan uraian diatas, penulis tertarik untuk melakukan penelitian terhadap "Aktivitas Bunga Ketepeng Cina (Senna alata L) terhadap jamur Candidia albicans" agar menjadi salah satu alternative pengobatan penyakit kulit yang disebabkan jamur Candida albicans terutama kurap yang bersumber dari bahan alam serta dapat meminimalkan efek samping yang tidak diinginkan seperti menjadi pada penggunaan antijamur.

\section{METODE PENELITIAN}

Penelitian ini adalah penelitian eksperimental, menggunakan ekstrak bunga ketepeng cina (Senna alata L.) menggunakan metode difusi untuk menguji aktivitas terhadap jamur Candida albicans. Populasi yang digunakan dalam penelitian ini adalah Bunga Ketepeng Cina (Senna alata L.) yang diperoleh dari Desa Tanah Abang Jaya Kabupaten Penukal Abab Lematang Ilir (PALI). Sampel penelitian ini adalah Ekstrak Bunga Ketepeng Cina (Senna alata L.). Banyak bunga yang diambil yaitu $4 \mathrm{~kg}$, bunga kering sebanyak $2,2 \mathrm{~kg}$ dan yang dibutuhkan 500 gram simplisia.

\section{HASIL PENELITIAN}

Hasil penelitian dari aktivitas antijamur ekstrak etanol bunga ketepeng cina (Senna alata L.) menggunakan 4 variasi konsentrasi ekstrak, dari ekstrak kental bunga ketepeng cina yang dilakukan diperoleh hasil sebagai berikut : 


\section{Ekstraksi Bunga Ketepeng Cina}

Sebanyak 500 gram serbuk bunga ketepeng cina yang telah disortasi basah dimaserasi dengan 3 liter etanol 96\% selama 3 X 24 jam, kemudian pelarut diuapkan dan diperoleh ekstrak kental bunga ketepeng cina158,5gr. Ekstraksi bunga ketepeng cina kering, dari bunga ketepeng cina segar $4 \mathrm{~kg}$ di keringkan diperoleh bunga ketepeng kering $2,2 \mathrm{~kg}$, kemudian bunga ketepeng kering 500 gr di maserasi dengan etanol $96 \%$ sebanyak 3 liter selama 3 X 24 jam, kemudian pelarut diuapkan dan diperoleh ekstrak kental bunga ketepeng cina 158,5 gr.

\section{Skrining Fitokimia}

Tabel 1. Hasil Skrining Fitokimia

\begin{tabular}{|c|c|c|c|c|}
\hline No. & $\begin{array}{l}\text { Identifikasi } \\
\text { Senyawa }\end{array}$ & Pereaksi & Parameter & Hasil \\
\hline 1. & Flavonoid & $\begin{array}{l}\mathrm{Mg}+ \\
\mathrm{HCl}\end{array}$ & $\begin{array}{l}\text { Kuning } \\
\text { Hingga } \\
\text { Merah }\end{array}$ & Positif \\
\hline 2. & Tanin & $\begin{array}{l}\text { Gelatin } \\
1 \% \\
\mathrm{FeCl} \\
1 \% \\
\end{array}$ & $\begin{array}{l}\text { Endapan } \\
\text { putih } \\
\text { Hitam } \\
\text { Kehijauan }\end{array}$ & $\begin{array}{l}\text { Positif } \\
\text { Positif }\end{array}$ \\
\hline 3. & Saponin & - & - & - \\
\hline 4. & Fenolik & $\mathrm{FeCl} 3$ & $\begin{array}{l}\text { Hijau } \\
\text { Kebiruan }\end{array}$ & Positif \\
\hline
\end{tabular}

Uji KHM Ekstrak Bunga Ketepeng Cina (Senna alata L) terhadap jamur Candida albicans

Tabel 4.2 Hasil Uji (KHM) Pada Jamur Candida albicans

\begin{tabular}{|c|c|c|c|c|c|}
\hline $\begin{array}{c}\text { Konsentrasi } \\
(\%)\end{array}$ & I & II & III & Rata-rata & KHM \\
\hline 40 & $7,1 \mathrm{~mm}$ & $7,2 \mathrm{~mm}$ & $7,4 \mathrm{~mm}$ & $7,1 \mathrm{~mm}$ & \multirow{6}{*}{$40 \%$} \\
\hline 60 & $12,0 \mathrm{~mm}$ & $12,2 \mathrm{~mm}$ & $12,5 \mathrm{~mm}$ & $12,2 \mathrm{~mm}$ & \\
\hline 80 & $13,2 \mathrm{~mm}$ & $13,3 \mathrm{~mm}$ & $13,5 \mathrm{~mm}$ & $13,3 \mathrm{~mm}$ & \\
\hline 100 & $14,0 \mathrm{~mm}$ & $14,2 \mathrm{~mm}$ & $14,4 \mathrm{~mm}$ & $14,2 \mathrm{~mm}$ & \\
\hline+ & & & & $13,1 \mathrm{~mm}$ & \\
\hline- & - & - & - & - & \\
\hline
\end{tabular}

Keterangan:

$\mathrm{K}+\quad$ : Ketokonazol

K- $\quad$ : Aqua Pro Injection

\section{PEMBAHASAN}

Evaluasi aktivitas antijamur ekstrak etanol bunga ketepeng cina (Senna alata $L$ ) meliputi skrining fitokimia dan uji aktivitas antijamur. Pada penelitian ini melakukan pengujian aktivitas antijamur dari ekstrak bunga ketepeng cina

(Senna alata L). Bahwa ada pengaruh ekstrak bunga ketepeng cina (Senna alata L) terhadap pertumbuhan jamur Candida albicans. Semakin meningkat konsentrasi ekstrak bunga ketepeng cina (Senna alata L) maka semakin meningkat pula zona hambatnya.

\section{a. Skrining Fitokimia}

Bedasarkan hasil skrining fitokimia golongan tanin menunjukkan Bunga ketepeng cina (Senna alata $L$ ) mengandung tanin yang ditandai dengan terbentuknya warna hitam kehijauan. Tanin merupakan senyawa aktif metabolit sekunder yang diketahui mempunyai beberapa khasiat yaitu sebagai antijamur. (Hindun, 2017)

Bedasarkan hasil skrining fitokimia golongan Fenolik diperoleh bunga ketepeng cina (Senna alata $L$ ) mengandung polifenol yang ditandai dengan terbentuknya warna jingga kecokelatan dan hijau kebiruan.

Bedasarkan metabolit sekunder diatas semua golongan merupakan bagian antibakteri. Antibakteri adalah zat yang dapat mengganggu pertumbuhan atau bahkan mematikan bakteri dengan cara mengganggu metabolisme mikroba yang merugikan. (Kusumastuti,2021)

Berdasarkan hasil diatas skrining fitokimia serbuk bunga ketepeng cina (Senna alata $L$ ) mengandung senyawa golongan flavonoid, tanin, dan fenolik. Hasil uji skrining fitokomia dapat dilihat pada tabel 1 .

\section{b. Uji Aktivitas Antijamur}

Uji aktivitas antijamur ekstrak bunga ketepeng cina (Senna alata L) yang diamati dan diukur dengan menggunakan jangka sorong. Hasil dari uji aktivitas antijamur dapat dilihat pada tabel 2 ekstrak 
bunga ketepeng cina (Senna alata $L$ ) yang menunjukkan bahwa masing-masing percobaan mengalami zona hambat yang berbeda-beda.

Berdasarkan hasil pengujian dengan menggunakan metode difusi dist diffusion, untuk menentukan konsentrasi hambat minimum (KHM) dapat dilihat dengan adanya zona bening. Pada konsentrasi $40 \%$ sudah menunjukan adanya zona bening dengan diameter ratarata pada jamur Candida albicans ATCC $7,1 \%$ mm. Pada konsentrasi 60\%, 80\% dan $100 \%$ rata-rata diameter zona bening semakin meningkat secara berurutan yaitu $60 \% 12,2 \mathrm{~mm}, 80 \% 13,3 \mathrm{~mm}$ dan $100 \%$ 14,2 mm. Untuk kontrol positif memiliki daya hambat $13,1 \mathrm{~mm}$. Sedangkan pada kontrol negatif tidak menunjukkan zona hambat sama kali.

\section{KESIMPULAN}

Dari hasil penelitian yang telah dilakukan membuktikan adanya aktivitas antijamur ekstrak bunga ketepeng cina (Senna alata L) terhadap jamur Candida albicans. Berdasarkan hasil penelitian bahwa aktivitas antijamur ekstrak etanol bunga ketepeng cina (senna alata L) pada konsentrasi $40 \%$ sudah mampu menghambat pertumbuhan jamur Candida albicans.

\section{SARAN}

\section{Bagi Stik Siti Khadijah Palembang}

Diharapkan dapat menambah pengetahuan dan wawasan bagi mahasiswa mengenai aktivitas antijamur ekstrak bunga ketepeng cina (Senna alata L) terhadap jamur Candida albicans. Dan hasil penelitian ini bisa dijadikan pengabdian kepada masyarakat.

\section{Bagi Masyarakat}

Diharapkan dapat menambah pengetahuan dan wawasan bagi masyarakat mengenai Tanaman
Bunga ketepeng cina (Senna alata L)Sebagai tanaman herbal Antijamur.

\section{Bagi peneliti selanjutnya}

Diharapkan dapat menggunakan metode dan cara lainnya, sehinnga penelitian tentang aktivitas antijamur ekstrak bunga ketepeng cina (Senna alata L) terhadap jamur Candida albicans bisa diketahui hasil penelitiannya dengan cara lain.

\section{DAFTAR PUSTAKA}

Alioes, Y. 2018. Uji potensi antijamur Candida albicans ekstrak daun gelinggang (Cassia alata L.) dibandingkan dengan sediaan daun sirih yang beredar di pasaran secara in vitro. Jurnal Kimia Riset, 3(2), 108-115.

Apriyani, A. S. 2020. Uji Daya Hambat Perasan Daun Melinjo (Gnetum gnemon L.) Terhadap Pertumbuhan Bakteri Esherichia coli. Poltekkes Kemenkes Yogyakarta.

Dewantoro, E. 2021. Efektivitas Ekstrak Daun Jamblang (Sygygium Cumini) Sebagai Pengobatan Ikan Tengadak (Barbonymusschwanenfeldii) Yang Diinfeksi Aeromonas hydrophila. Jurnal Borneo Akuatika, 3(1).

Dewi, I. S. 2021. Uji Aktivitas Anti Aging Sediaan Krim Berbahan Aktif Kombinasi Ekstrak Lidah Buaya (Aloe vera) Dan Alga Hijau (Haematococcus pluvialis). UIN Raden Intan Lampung.

Egra, P. S., Patriawan, R., Kartinam, S. S., \& Kusparidin, H. 2019. Aktivitas Antimikroba Tanaman Paku (Stenochlaena palustris dan Pteridium caudatum) Terhadap Bakteri (Ralstonia solanacearum dan Streptococcus sobrinus). Jurnal Jamu Indonesia, 4(1), 28-36. 
Fajri, M. 2018. Aktivitas Antifungi Daun Ketepeng Cina (Cassia alata L.) Fraksi Etanol, N-Heksan, Dan Kloroform Terhadap Jamur Microsporum canis. University of Darussalam Gontor.

Harahap, M. I., \& Sitepu, S. F. 2019. Uji Evektifitas Eksudat Akar BangunBangun (Coleus amboimicus) untuk Menghambat Pertumbuhan Jamur Akar Putih (Rigidoporus micropus) di Laboratorium: Test the Effectiveness of the Bangun-bangun (Coleus amboimicus) Root Exudate to Inhibit the Growth of Whit. Jurnal Online Agroekoteknologi, 7(2), 415422.

Heliawati, L., Suchyadi, Y., \& Iryani, A. 2018. Kimia Organik 2. Bogor: LPPM Universitas Pakuan.

Hendrawan, A. 2019. Gambaran Tingkat Pengetahuan Tenaga Kerja Pt'X'Tentang Undang-Undang Dan Peraturan Kesehatan Dan Keselamatan Kerja. Jurnal Delima Harapan, 6(2), 69-81.

Hujjatusnaini, N. 2007. Uji Potensi Ekstrak Daun Ketepeng Cina (Cassia alata L.) Terhadap Penghambatan Pertumbuhan Trichophyton sp. Elqudwah.

Juli Angriyasa, I. K. 2018. Hubungan Pengetahuan Personal Hygiene Dengan Gejala Penyakit Kulit Pada Pemulung Di Tempat Pembuangan Akhir Sampah Suwung Tahun 2018 Studi Dilaksanakan Di Tpa Sampah Suwung Kecamatan Denpasar Selatan. Jurusan Kesehatan Lingkungan.

Kusuma Wahyuni, D., Ekasari, W., Witono, J. R., \& Purnobasuki, H. 2016. Toga indonesia. Airlangga University Press.
Maimunah, E. 2018. Uji Efektivitas Air Buah Jeruk Nipis (Citrus aurantifolia) Dalam Menghambat Candida albicans (Studi di STIKes ICMe Jombang). STIKES Insan Cendekia Medika Jombang.

Makhfirah, N., Fatimatuzzahra, C., Mardina, V., \& Hakim, R. F. 2020. Pemanfaatan Bahan Alami Sebagai Upaya Penghambat Candida albicans Pada Rongga Mulut. Jurnal Jeumpa, 7(2), 400-413.

Mukhriani, M. 2014. Farmakognosi Analisis.

Muthmainnah, B. 2019. Skrining Fitokimia Senyawa Metabolit Sekunder Dari Ekstrak Etanol Buah Delima (Punica granatum L.) Dengan Metode Uji Warna. Media Farmasi, 13(2), 3641.

Novita, W. 2016. Uji Aktivitas Antibakteri Fraksi Daun Sirih (Piper betle L) Terhadap Pertumbuhan Bakteri Streptococcus Mutans Secara In Vitro. Jambi Medical Journal" Jurnal Kedokteran dan Kesehatan", 4(2).

Pratiwi, S. T. 2008. Mikrobiologi farmasi.

Putri, H. E. 2016. Uji Antifungi Fraksi Etanol Daun Jatropha gossypifolia Terhadap Jamur Candida albicans Dengan Metode Difusi Cakram. University of Muhammadiyah Malang.

Rahma, N. 2020. Efektivitas Ekstrak Rumput Laut Sargassum polycystum Sebagai Antibakteri Vibrio spp. Universitas Hasanuddin.

Rahman, A., Taufiqurrahman, I., \& Edyson, E. 2019. Perbedaan Total Flavonoid Antara Metode Maserasi Dengan Sokletasi Pada Ekstrak Daun 
Ramania (Bouea macrophylla Griff) (Studi pendahuluan terhadap proses pembuatan sediaan obat penyembuhan luka). Dentin, 1(1)

Rahmasari, B. 2019. Penggunaan Ekstrak Daun Sengon Sebagai Biosurfaktan Dalam Pembuatan Biodetergen Cair Ditinjau Dari Keragaman Temperatur Dan Kecepatan Pengadukan. Politeknik Negeri Sriwijaya.

Rindi Astari, S. 2020. UJI EFEKTIVITAS EKSTRAK DAUN ALPUKAT (Persea americana) TERHADAP PERTUMBUHAN JAMUR Candida albicans. Poltekkes Tanjungkarang.

Rohama, R., \& Zainuddin, Z. 2021. Identifikasi Senyawa Metabolit Sekunder pada Ekstrak Daun Gayam (Inocarpus Fagifer Fosb) dengan Menggunakan KLT. Jurnal Surya Medika (JSM), 6(2), 125-129.

Romadhoni, N. R. T. 2020. Uji aktivitas antimikroba nanopartikel kombinasi allium sativum linn., curcuma mangga val. dan acorus calamus 1 . secara in vitro. Universitas Islam Negeri Maulana Malik Ibrahim.

Safitri, E. K. A. R. I. A., \& Rohama, R. 2020. Skrining Fitokimia Serta Uji Aktivitas Antioksidan Ekstrak Bunga Ketepeng Cina (Senna alata L.) Dengan Metode DPPH. Journal of Pharmaceutical Care and Sciences, 1(1), 10-18.

Setyaningrum, N., \& Kemila, M. 2018. Evaluasi Terapi Penyakit Akne Vulgaris Dan Dermatitis Kontak Alergi Di Rumah Sakit Umum Daerah Wirosaban Yogyakarta.

Siburian, D. N. 2019. Karya Tulis Ilmiah Uji Efek Antibakteri Ekstrak Etanol Daun Kenikir (Cosmos caudatus
Kunth) Terhadap Pertumbuhan Bakteri Escherichia coli Dengan Pembanding Kloramfenikol.

Silvia, D. 2018. Uji aktivitas antifungi ekstrak kulit buah jeruk nipis (Citrus aurantifolia) terhadap jamur Candida albicans. UIN Sunan Ampel Surabaya.

Siregar, I. T. H. S., \& Suhendry, I. I. 2013. Budi Daya \& Teknologi Karet. Penebar Swadaya Grup.

Solahhudien, S., Eosina, P., Fajri, H., \& Ridwan, T. 2019. Sistem Informasi Stok Obat Simplisia (SISOP). Seminar Nasional Teknologi Informasi, 2, 331-334.

Supriyanto, G. 2018. SNP-SK-2 (01-01) Pemakalah Utama Adsorpsi Dan Degradasi Polutan Menggunakan Bahan Baku Lokal Termodifikasi. Prosiding, 1.

Telaumbanua, E. A. 2019. Formulasi Krim Ekstrak Etanol Daun Mindi (Melia azedarach L.) Dan Uji Daya Hambat Terhadap Candida Albicans. Institut Kesehatan Helvetia.

Vernanda, R. Y. 2015. Pengaruh Sarang Semut (Myrmecodia pendans) Pada Tikus Infardk Miokard Ditijau Dari Kadar Mda, Sod Dan Gambaran Histologi Jantung. Farmasi. 
